
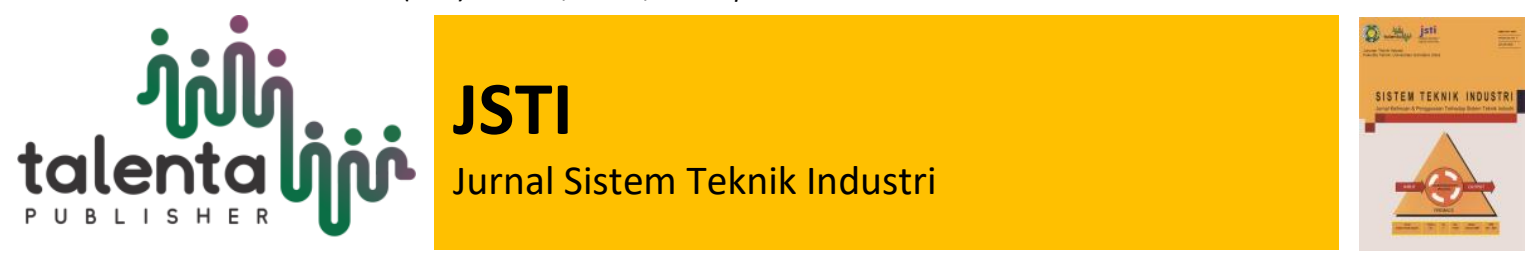

\title{
Risk Mitigation Analysis of Fish Cracker Products Supply Chain Using House Of Risk Method Case Study: Sri Tanjung Cracker Company
}

\author{
Derma Fitriani ${ }^{1}$, Asep Erik Nugraha ${ }^{2}$ \\ ${ }^{1,2}$ Industrial Engineering Study Program, Faculty of Engineering, Universitas Singaperbangsa \\ Karawang, Karawang, Indonesia
}

\begin{abstract}
The Sri Tanjung Cracker Company is an MSME that produces fish crackers. Currently, the Sri Tanjung cracker company lacks structured risk management, particularly in supply chain activities One of the known risks is that companies run out of raw materials, suppliers who ship late, and defective products. The goal of this study was to identify risks and develop appropriate preventive measures to reduce risks in the fish cracker production supply chain. This study maps supply chain operations using the SCOR model then uses the HOR method to classify risks and related mitigation strategies using Pareto diagrams and a probability impact matrix model. The results showed that the HOR phase 1 model comprises 60 risk events, 35 risk agents, and 7 priority risk agents for HOR phase 2 computation. HOR phase 2 shows 4 mitigation strategies that need to be addressed first. To conduct further research, if the suggested action is in the form of preventive action, it is required to quantify the impact of risk reduction and can add variables in the review of risk events, risk agents, and preventive measures to identify supply chain activities at the Sri Tanjung Fish Cracker Company.
\end{abstract}

Keyword: House of Risk (HOR), Risk, Supply Chain

\begin{abstract}
Abstrak. Perusahaan Kerupuk Sri Tanjung merupakan UMKM yang memproduksi kerupuk ikan. Saat ini, perusahaan kerupuk Sri Tanjung belum memiliki manajemen risiko yang terstruktur, khususnya dalam aktivitas rantai pasok. Salah satu risiko yang diketahui adalah perusahaan kehabisan bahan baku, pemasok yang terlambat mengirim, dan produk cacat. Tujuan dari penelitian ini adalah untuk mengidentifikasi risiko dan mengembangkan tindakan pencegahan yang tepat untuk mengurangi risiko dalam rantai pasokan produksi kerupuk ikan. Studi ini memetakan operasi rantai pasok menggunakan model SCOR kemudian menggunakan metode HOR untuk mengklasifikasikan risiko dan strategi mitigasi terkait menggunakan diagram Pareto dan model matriks dampak probabilitas. Hasil penelitian menunjukkan bahwa model HOR fase 1 terdiri dari 60 kejadian risiko, 35 agen risiko, dan 7 agen risiko prioritas untuk perhitungan HOR fase 2. HOR fase 2 menunjukkan 4 strategi mitigasi yang perlu ditangani terlebih dahulu. Untuk melakukan penelitian lebih lanjut, jika tindakan yang disarankan berupa tindakan preventif, maka diperlukan untuk mengukur dampak pengurangan risiko dan dapat menambahkan variabel dalam tinjauan kejadian risiko, agen risiko, dan tindakan pencegahan untuk mengidentifikasi kegiatan rantai pasokan di Perusahaan Kerupuk Ikan Sri Tanjung.
\end{abstract}

Kata Kunci: House of Risk (HOR), Risiko, Supply Chain

Received 01 September 2021 | Revised 24 December 2021 | Accepted 01 January 2022

*Corresponding author at: Universitas Siperbangsa Karawang, Karawang, Indonesia

E-mail address: 1810631140126@student.unsika.ac.id

https://doi.org/10.32734/jsti.v24i1.6879 Attribution-NonCommercial-ShareAlike 4.0 International.License Some rights reserved Copyright (C 2022 Published by Talenta Publisher, ISSN: 1411-5247 e-ISSN: 2527-9408

Journal Homepage: http://talenta.usu.ac.id/jsti 


\section{Introduction}

In its development in the industrial sector, the competition is getting tougher and more global, especially in the development of information technology which makes customer demands higher in facing challenges that are increasingly changing and getting tougher from time to time. Companies must compete to be better companies the Sri Tanjung Cracker Company is asked to be able to compete with other companies. Supply chain management is a critical aspect of every business because it encompasses all aspects of a manufacturing operation, from suppliers to customers [1]. So that it may establish a strong supply chain network in its application, which is one component of the company's plan to compete with other companies.

The Sri Tanjung Cracker Company is an MSME that is active in the production sector, especially in the production of fish crackers. As a company that continues to grow, the Sri Tanjung Cracker Company is asked to be able to compete with other companies. To compete with competitors, Sri Tanjung Crackers Company must establish a reliable supply chain flow that protects the company from a variety of risks that could lead to the failure of the company's goal of meeting demand and increasing customer satisfaction, so companies must focus on an effective and efficient production process. The Sri Tanjung Cracker Company currently lacks organized risk management, necessitating effort in the areas of risk identification and mitigation, particularly in supply chain activities. Uncertainty about supply chain risks necessitates risk management to lower the level of risk that can be harmful and have an influence on the company's business processes [2].

Based on interviews that have been conducted with the company, it is known that currently, the company in carrying out supply chain activities for the manufacture of its fish cracker products has run out of raw materials, especially fish raw materials which are one of the main raw materials for fish cracker production at the Sri Tanjung Cracker Company. Running out of raw materials is caused by suppliers who arrived late in delivery and the lack of fish raw materials ordered. As a result, the supply of fish raw materials is reduced which has an impact on the planning of the fish cracker production process experiencing delays. Then there are various other risks discovered in the company's fish cracker production supply chain activities, such as a shortage of finished goods to be sent to customers, defective fish cracker products that frequently occur due to insufficient inspection by workers (human error), and delays in product delivery to customers, and rejects during the manufacturing process. As a result, risk analysis and the development of mitigation methods are required to reduce supply chain risks [3].

To overcome these risks, according to [4] the House of Risk (HOR) model is used to identify, analyze, evaluate and treat risks in mitigating risks. Pujawan and Geraldin have created a framework in which the FMEA (Failure Mode and Effect Analysis) and QFD (Quality Function Deployment) methods can be used. The steps in this framework are divided into two stages, the first of which is risk identification and the second of which is risk management. The risk identification stage is where the risk event occurs, the source of the risk is identified, and the 
risk's value is calculated. The risk management stage is the risk agent selection phase from the first stage of handling actions or mitigation measures [3].

The following are the findings of earlier risk-mitigation research that were used as a reference or parameter in this study. Research conducted by [5] used the SCOR and HOR models to identify hazards in supply chain activities in IKM Tahu Bandung Sutra. The house of risk method is used in research undertaken by [6] to determine the risk of material and component delays in the Ro-Ro 300 GT Lake Toba shipbuilding project. [7] performed research at PT. MCS uses a combined model method of SCOR, house of risk, and probability impact matrix to identify all risk events and risk sources in pallet and dunnage supply chain systems and prioritize risk source mitigation operations. Meanwhile, study [8] employs the SCOR and HOR models to manage risk in Nicesy MSMEs' doughnut product supply chain activities. Meanwhile, based on prior research, [9] employs the GSCOR model and the house of risk technique to analyze and reduce supply chain risks for the Bogie S2HD9C manufacturing at PT Barata Indonesia. To see the risk conditions well before or after being treated or mitigated, use the Supply Chain Operation Reference (SCOR) method to identify supply chain work activities and classification using Pareto diagrams and mapping the probability impact matrix model for House of Risk phase 1 and House of Risk phase 2.

Based on the problems that exist in the supply chain system at the Sri Tanjung Fish Cracker Company and previous research, the purpose of this study is to identify risks that arise in the supply chain of fish cracker production and develop effective prevention methods to reduce risk using a combined SCOR model approach, house of risk, and probability impact matrix. With the risk management research, it is hoped that the company will be able to overcome risks by using appropriate risk handling and considering the proposed risk mitigation design to implement it in a more effective and efficient supply chain system at the Sri Tanjung Fish Cracker Company.

\section{Related Work}

The following are some of the results of previous studies that have been carried out and used as parameters in the study. Research conducted by Asep Ridwan, Dyah Lintang Trenggonowati, and Vivit Parida: The results of this study are in the form of mitigation actions in halal supply chain risks in IKM Tahu Bandung [5]. Maria Elfrida Sibuea and Hadi Sutanto Saragi conducted the following research: Material and component delays in the 300 GT Lake Toba Ro-Ro Ship construction project have been discovered as a result of risk mitigation activities using the house of risk method [6]. Research conducted by Asep Ridwan, Putro Ferro Ferdinant, and Wahyuni Ekasari: The results of this study are a risk mitigation design for pallet and dunnage supply chain systems using the house of risk method at PT MCS [7]. Research conducted by Maria Ulfah: There is a risk mitigation action in the donut product supply chain using the house of risk method in Nicesy MSMEs [8]. Maghfur Rozudin and Nina Aini Mahbubah conducted research: The findings of this study include the use of the house of the risk model in managing the green supply chain risk of S2HD9C bogie products at PT Barata Indonesia [9]. 


\section{Methodology}

This study's methodology employs a flow chart that depicts the processes involved in doing research. The data for this study was gathered through observation, interviews, and brainstorming sessions with relevant and competent parties at the Sri Tanjung Cracker Company. Where the observations are the risk problems that occur in the Sri Tanjung Cracker Company's supply chain activities. Researchers also conducted interviews with competent company managers and brainstormed by checking each supply chain procedure to obtain a company-approved statement connected to risk occurrences and supply chain risk sources. Then fill in severity for risk events, occurrence for risk sources, and the correlation between the two in the supply chain at the Sri Tanjung Fish Cracker Company. Figure 1 depicts the flow chart.

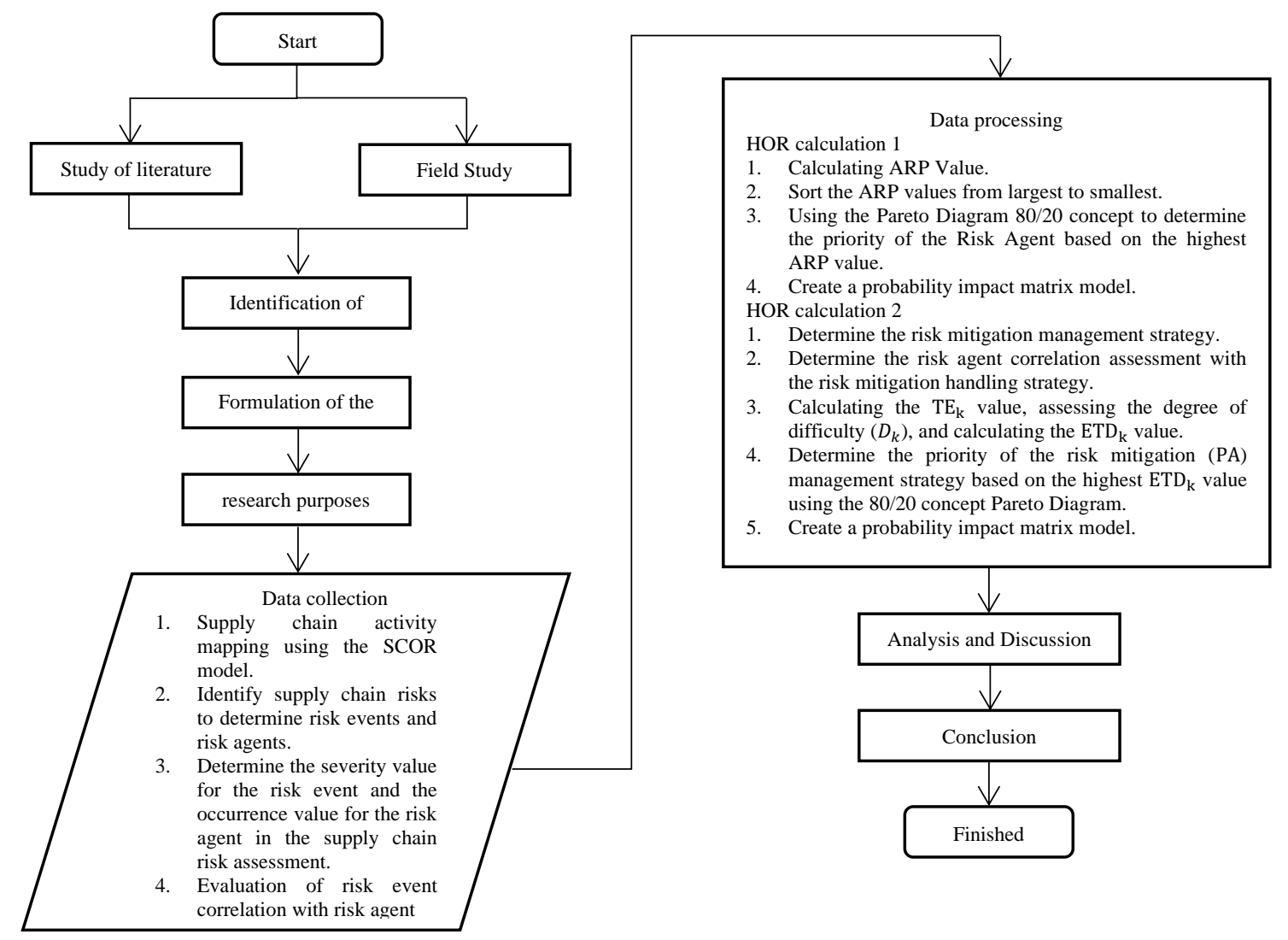

Figure 1 Research Flowchart

\subsection{House of Risk}

The House of Risk method is a more active risk management strategy in which the risk agent who has been recognized as the source of the risk event can control it by issuing orders based on the degree of the potential repercussions. Based on this sequence, it is also possible to determine more active and effective actions to eliminate the opportunity for the risk to arise [10]. HOR itself is divided into two stages, namely:

1. House of Risk (HOR) phase 1 (HOR) is utilized to decide which risk agents should be prioritized for action. There are several steps or things that must be done in HOR phase 1, namely: 
- Identify risk events and assess the likelihood of each risk agent occurring in each business process. Risk identification at this stage can be mapped using the Supply Chain Operation Reference (SCOR) model according to the respective supply chain business processes.

- Each processing activity is identified as a risk event $\left(\mathrm{E}_{\mathrm{i}}\right)$ then an assessment of the severity $\left(\mathrm{S}_{\mathrm{i}}\right)$ is carried out.

- Identify the risk agent $\left(\mathrm{A}_{\mathrm{i}}\right)$ and use an Occurrence $\left(\mathrm{O}_{\mathrm{j}}\right)$ evaluation to determine the likelihood of each risk source occurring.

- The correlation or association between the risk event $\left(E_{i}\right)$ and the risk agent $\left(A_{i}\right)$ is measured. By measuring the correlation $\left(\mathrm{R}_{\mathrm{ij}}\right)$ including $0,1,3$, and 9 .

- Calculates ARP which is the overall risk that can be calculated from the result or value of agent $\mathrm{j}\left(\mathrm{ARP}_{\mathrm{j}}\right)$. The formula for calculating the Aggregate Risk Potential value is:

$$
A R P_{j}=O_{j} \times \sum S_{i} R_{i j}
$$

- Risk agents $\left(A_{j}\right)$ are ranked from highest score to lowest score according to the ARP score.

Table 1 House of Risk phase 1

\begin{tabular}{|c|c|c|c|c|c|c|c|}
\hline \multirow{2}{*}{$\begin{array}{l}\text { Business } \\
\text { Process }\end{array}$} & \multirow{2}{*}{$\begin{array}{c}\text { Risk } \\
\text { Even } t \\
\left(E_{i}\right)\end{array}$} & \multicolumn{5}{|c|}{ Risk Agent $\left(A_{i}\right)$} & \multirow{2}{*}{$\begin{array}{c}\text { Severity of } \\
\text { Risk Event I } \\
\left(S_{i}\right)\end{array}$} \\
\hline & & A1 & $A 2$ & $A 3$ & A4 & $A 5$ & \\
\hline \multirow[t]{2}{*}{ Plan } & $E 1$ & RII & $R I 2$ & R13 & & & $S 1$ \\
\hline & $E 2$ & $R 12$ & $R 13$ & & & & $S 2$ \\
\hline \multirow{2}{*}{ Source } & $E 3$ & $R 13$ & RI4 & & & & $S 3$ \\
\hline & E4 & R14 & & & & & 54 \\
\hline \multirow[t]{2}{*}{ Make } & E5 & $R 15$ & & & & & $S 5$ \\
\hline & E6 & & & & & & S6 \\
\hline \multirow[t]{2}{*}{ Deliver } & $E^{7}$ & & & & & & $s_{7}$ \\
\hline & $E 8$ & & & & & & s8 \\
\hline Return & E9 & & & & & & s9 \\
\hline $\begin{array}{l}\text { Occurence of } \\
\text { agent } j\end{array}$ & & $O I$ & $O 2$ & O3 & $O 4$ & O5 & \\
\hline $\begin{array}{l}\text { Aggregate risk } \\
\text { potential } j \\
\text { Priority rank of } \\
\text { agent } j\end{array}$ & & $A R P 1$ & $A R P 2$ & $A R P 3$ & $A R P 4$ & $A R P 5$ & \\
\hline
\end{tabular}

2. House of Risk (HOR) phase 2 (HOR) is used to establish the actions that must be prioritized and the cost resource management that must be regarded as effective. The steps for calculating ARP in HOR phase 2 are as follows:

- Risk agents $\left(\mathrm{A}_{\mathrm{j}}\right)$ that have been selected with priority ranking through Pareto diagram analysis according to the $\mathrm{ARP}_{\mathrm{j}}$ value and probability impact matrix model.

- Then identification is carried out by considering the appropriate preventive action $\left(\mathrm{PA}_{\mathrm{k}}\right)$ in the prevention of risk agent $\left(\mathrm{A}_{\mathrm{j}}\right)$ which was previously selected in the first stage. 
- Measuring the correlation $\left(E_{j k}\right)$ between each $P A_{k}$ and the risk agent $\left(A_{j}\right)$ using a correlation scale of $0,1,3$, and 9. Calculate the total value of effectiveness $\left(\mathrm{TE}_{\mathrm{k}}\right)$ for each of the $\mathrm{k}$ actions using the formula:

$$
T E_{k}=\sum A R P_{j} E_{j k}
$$

- Assessing the Degree of Difficulty for each preventive action symbolized by $D_{k}$. The following formula can be used to calculate the total value of the effectiveness to difficulty ratio $\left(\mathrm{ETD}_{\mathrm{k}}\right)$ :

$$
E T D_{k}=T E_{k} / D_{k}
$$

- Prioritize each preventive action $\left(\mathrm{R}_{\mathrm{k}}\right)$ from the highest to the lowest total ratio value $\left(\mathrm{ETD}_{\mathrm{k}}\right)$. In addition, to carry out prioritized mitigation actions, create a Pareto diagram of the value of the effectiveness to difficulty ratio $\left(\mathrm{ETD}_{\mathrm{k}}\right)$. Then mapping of priority risk management/mitigation strategies is carried out using the probability impact matrix model.

\begin{tabular}{|c|c|c|c|c|c|c|}
\hline \multirow{4}{*}{$\begin{array}{c}\text { To be treated risk } \\
\text { agent }(\mathrm{Aj}) \\
A 1 \\
A 2\end{array}$} & \multicolumn{5}{|c|}{ Preventive action (PAk) } & \multirow{4}{*}{$\begin{array}{c}\text { Aggregate risk } \\
\text { potentials (ARPj) } \\
\text { ARP1 } \\
\mathrm{ARP}_{2}\end{array}$} \\
\hline & \multirow{5}{*}{$\begin{array}{l}P A 1 \\
E 11\end{array}$} & \multirow[t]{5}{*}{$P A 2$} & \multirow[t]{5}{*}{$P A 3$} & \multirow[t]{5}{*}{ PA4 } & \multirow[t]{5}{*}{$P A 5$} & \\
\hline & & & & & & \\
\hline & & & & & & \\
\hline$A 3$ & & & & & & $\mathrm{ARP}_{3}$ \\
\hline$A 4$ & & & & & & $\mathrm{ARP}_{4}$ \\
\hline $\begin{array}{l}\text { Total effectiveness of } \\
\text { action } k\end{array}$ & $T E 1$ & TE2 & TE3 & TE4 & TE5 & \\
\hline $\begin{array}{l}\text { Degree of difficulty } \\
\text { performing action } k\end{array}$ & DI & D2 & D3 & D4 & D5 & \\
\hline $\begin{array}{l}\text { Effectiveness to } \\
\text { difficulty ratio }\end{array}$ & ETDI & ETD2 & ETD3 & ETD4 & ETD5 & \\
\hline Rank of priority & $R I$ & $R 2$ & $R 3$ & $R 4$ & R5 & \\
\hline
\end{tabular}

Table 2 House of Risk phase 2

\subsection{Probability Impact Matrix}

The probability impact matrix uses the probability value and the effective value to establish the risk priority areas [11]. The probability impact matrix only uses two key variables to establish risk priority: the severity value and the occurrence value. Meanwhile, the RPN calculation uses three key variables to assess the level of risk: severity, occurrence, and detection [12].

Table 3 Probability Impact Matrix

\begin{tabular}{|c|c|c|c|c|c|c|}
\hline \multirow{2}{*}{ Chance level (Occurrence) } & \multicolumn{5}{|c|}{ Impact Level (Severity) } \\
\cline { 3 - 7 } & 1 & 2 & 3 & 4 & 5 \\
\cline { 3 - 6 } & Very Low & Low & Medium & Height & Very High \\
\hline 5 & Very High & & & & & \\
\hline 4 & Height & & & & & \\
\hline 3 & Medium & & & & & \\
\hline 2 & Low & & & & & \\
\hline 1 & Very Low & & & & & \\
\hline
\end{tabular}




\section{Result and Discussion}

\subsection{Job Activity Mapping}

Mapping supply chain activities is the process of categorizing supply chain operations. The SCOR model is used to map activities in the supply chain, making it easy to identify each one. The Supply Chain Operation Reference (SCOR) model is made up of five processes: plan, source, make, deliver, and return. Activity mapping begins with data collection through interviews and brainstorming with competent parties and observations at the Sri Tanjung Cracker Company. Table 2 shows the results of mapping activities at the Sri Tanjung Cracker Company based on the SCOR model at the Sri Tanjung Cracker Company.

Table 4 Sri Tanjung Cracker Company Activities based on SCOR

\begin{tabular}{clc}
\hline Process & \multicolumn{1}{c}{ Activity } & Code \\
\hline \multirow{6}{*}{ Plan } & Demand forecast & C1 \\
& Fish raw material inventory planning & C2 \\
& Production planning & Crocurement planning \\
& Financial planning & C4 \\
& Capacity planning & C5 \\
& Machine maintenance planning & C6 \\
& Supplier selection & C7 \\
\hline \multirow{5}{*}{ Source } & Fish raw material delivery planning & C8 \\
& Receipt of raw materials from suppliers & C1 \\
& Supplier raw material quality inspection & C11 \\
& The Raw material procurement process & C12 \\
\hline \multirow{4}{*}{ Make } & Production scheduling planning & C13 \\
& Production process & C14 \\
& Product quality inspection & C15 \\
& Storage of finished goods in warehouse & C16 \\
\hline \multirow{3}{*}{ Deliver } & Supplier delivery selection & C17 \\
& Finished product delivery & C18 \\
& Warehousing activities & C19 \\
\hline \multirow{2}{*}{ Return } & Return of rejected products & C20 \\
& Return of reject raw materials & C21 \\
\hline
\end{tabular}

Based on the identification process using the SCOR model at the Sri Tanjung Cracker Company in the supply chain flow. In each of the Sri Tanjung Cracker Company's supply chain processes, there are 21 results of mapping operations on the SCOR model. The planning process is comprised of 7 detailed activities. The source process is made up of 5 detailed activities. There are 4 detailed actions in the making process. The delivery process consists of 3 detailed activities. While the return process there are 2 details of activities.

\subsection{House of Risk Phase 1 (Risk Identification Phase)}

1. Risk Identification

The first stage of the house of risk (HOR) process is risk identification. At this step, the identification of hazards that may emerge during supply chain activities. The risk 
identification stage includes the identification of the risk agent $\left(A_{i}\right)$ of the risk event $\left(E_{i}\right)$ that occurs, the risk assessment which includes the assessment of the level of impact $\left(S_{i}\right)$ with a scale of 1 to 10 , where 1 means there is no disturbance and 10 means there is a risk impact. As well as a risk assessment for the amount of occurrence $\left(\mathrm{O}_{\mathrm{j}}\right)$ on a scale of 1 to 10 , with 1 indicating that it will almost surely occur and 10 indicating that it will very certainly occur [13]. The stages of risk identification in the Sri Tanjung Cracker Company supply chain are carried out by brainstorming and direct interviews with the company regarding what risks occur and the causes of these risks. Table 3 is a risk event $\left(\mathrm{E}_{\mathrm{i}}\right)$ that has been detected in the Sri Tanjung Cracker Company's supply chain and has been assessed for severity $\left(\mathrm{S}_{\mathrm{i}}\right)$ on a scale of 1-10.

Table 5 Risk Events

\begin{tabular}{|c|c|c|c|c|}
\hline Process & Code & Risk Event & $\mathbf{E i}$ & Severity \\
\hline \multirow{17}{*}{ Plan } & C1 & $\begin{array}{l}\text { Determination of forecasting the number of less precise } \\
\text { requests }\end{array}$ & E1 & 7 \\
\hline & \multirow{6}{*}{$\mathrm{C} 2$} & $\begin{array}{l}\text { The discrepancy between the written stock of fish raw } \\
\text { materials and those available in the warehouse }\end{array}$ & E2 & 6 \\
\hline & & $\begin{array}{l}\text { Mistakes in recording the specifications of the fish raw } \\
\text { materials requested }\end{array}$ & E3 & 6 \\
\hline & & Incorrect inventory size & E4 & 6 \\
\hline & & The need for fish raw materials came suddenly & E5 & 5 \\
\hline & & Instability of fish raw material prices & E6 & 5 \\
\hline & & A sudden change of production planning & E7 & 7 \\
\hline & \multirow{4}{*}{$\mathrm{C} 3$} & Production scheduling delay & E8 & 7 \\
\hline & & Improper production scheduling & E9 & 7 \\
\hline & & Orders suddenly change from customers & E10 & 4 \\
\hline & & Inappropriate budget plan & E11 & 7 \\
\hline & \multirow[t]{2}{*}{$\mathrm{C} 4$} & Customer ambiguity when ordering & E12 & 4 \\
\hline & & A miscalculation in planning raw material requirements & E13 & 6 \\
\hline & \multirow[t]{2}{*}{ C5 } & $\begin{array}{l}\text { The imbalance between reality and predetermined financial } \\
\text { planning }\end{array}$ & E14 & 5 \\
\hline & & Incompatibility of supply chain with financial planning & E15 & 6 \\
\hline & C6 & $\begin{array}{l}\text { Capacity planning that is less precise than what has been } \\
\text { determined }\end{array}$ & E16 & 7 \\
\hline & $\mathrm{C} 7$ & $\begin{array}{l}\text { Negligence of machine maintenance scheduling not as } \\
\text { planned }\end{array}$ & E17 & 8 \\
\hline \multirow{11}{*}{ Source } & \multirow{3}{*}{$\mathrm{C} 8$} & The poor communication process with suppliers & E18 & 7 \\
\hline & & Sudden termination of the contract & E19 & 7 \\
\hline & & Error determining supplier & $\mathrm{E} 20$ & 7 \\
\hline & C9 & Late delivery of fish raw materials & $\mathrm{E} 21$ & 8 \\
\hline & \multirow[t]{2}{*}{$\mathrm{C} 10$} & $\begin{array}{l}\text { There was an error in the raw fish material received from the } \\
\text { supplier }\end{array}$ & E22 & 7 \\
\hline & & Incomplete quantity of fish raw materials sent from suppliers & E23 & 6 \\
\hline & \multirow{3}{*}{ C11 } & $\begin{array}{l}\text { The quality of fish raw materials that do not meet the } \\
\text { company's standards }\end{array}$ & E24 & 5 \\
\hline & & Negligence of workers when checking received raw materials & $\mathrm{E} 25$ & 5 \\
\hline & & The fish raw material is damaged & E26 & 6 \\
\hline & \multirow[b]{2}{*}{$\mathrm{C} 12$} & Error raw fish sent by a supplier & E27 & 6 \\
\hline & & Lack of skills and abilities of workers & $\mathrm{E} 28$ & 4 \\
\hline \multirow{3}{*}{ Make } & \multirow{3}{*}{$\mathrm{C} 13$} & Lack of workers & E29 & 4 \\
\hline & & Accident at work & E30 & 6 \\
\hline & & Unable to meet customer demand & E31 & 5 \\
\hline
\end{tabular}




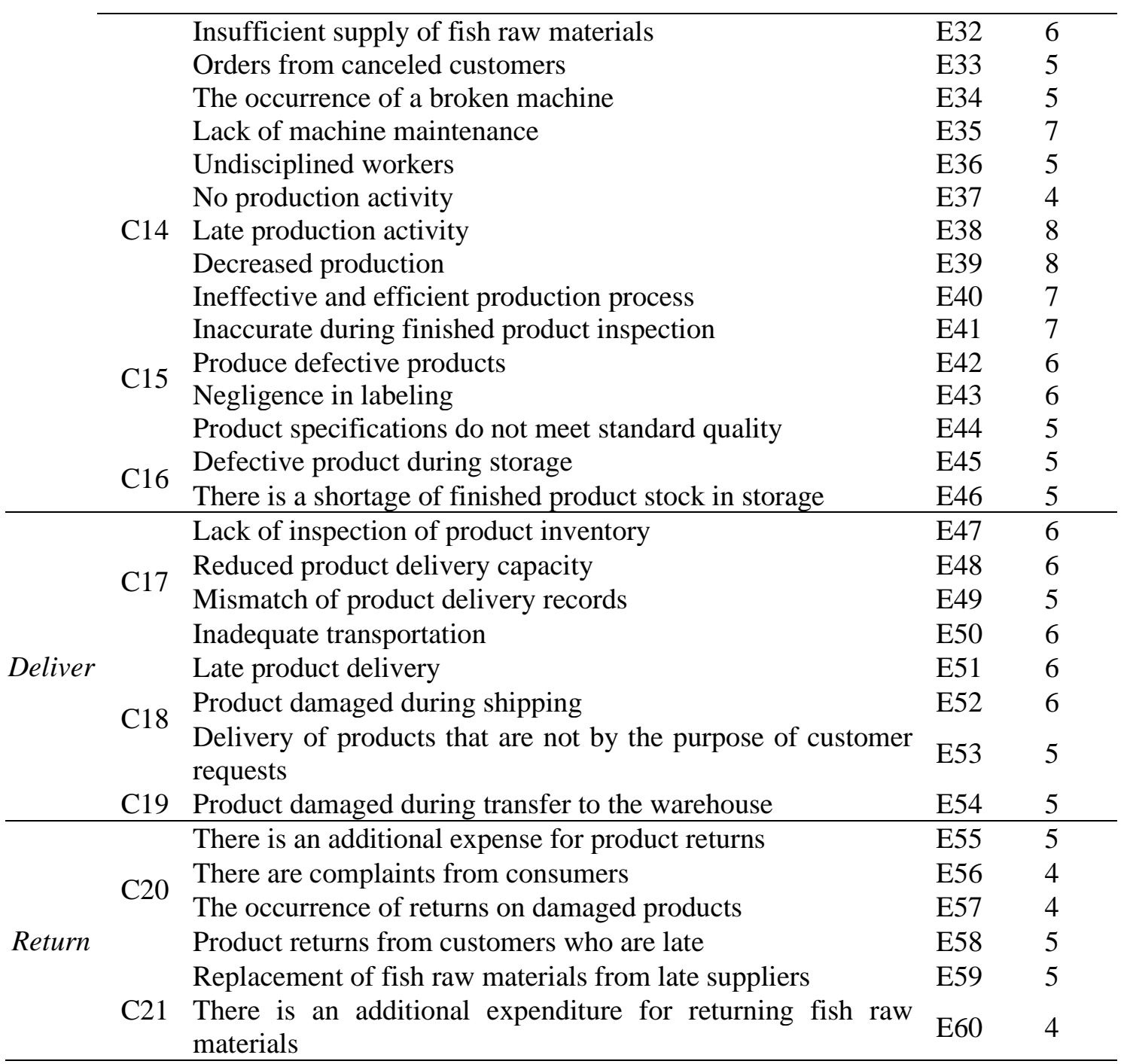

Based on the results of risk event identification $\left(\mathrm{E}_{\mathrm{i}}\right)$ from the risks that occur in the supply chain of the Sri Tanjung Cracker Company, 60 risk events $\left(E_{i}\right)$ were identified with four severity levels $\left(\mathrm{S}_{\mathrm{i}}\right)$ the highest being negligence in scheduling machine maintenance that was not as planned, delays in the delivery of fish raw materials, delays in production activities, and a decrease in production, namely 8 .

The next step is to determine what is causing the risk (risk agent). The source of risk (risk agent) is a factor that causes risk occurrences to occur, necessitating the deployment of preventative measures. The risk agent $\left(A_{i}\right)$ shown in table 4 has been identified in the Sri Tanjung Cracker Company's supply chain and has been assessed for occurrence $\left(\mathrm{O}_{j}\right)$ on a scale of 1-10. The chance of an event occurring extremely infrequently is represented by the value of $\left(\mathrm{O}_{\mathrm{j}}\right)$ occurrence 1 , whereas the likelihood of an event occurring very frequently is represented by the number of 10 . 
Table 6 Identification of Risk Agents

\begin{tabular}{lcc}
\hline \multicolumn{1}{c}{ Risk Agent } & Ai & Occurrence \\
\hline Demand forecasting is less accurate & A1 & 7 \\
An uncertain number of requests from customers & A2 & 6 \\
Misinformation and communication obtained & A3 & 6 \\
Human error & A4 & 7 \\
Lack of coordination & A5 & 7 \\
Purchase notes do not contain clear details & A6 & 5 \\
Inadequate measuring tools & A7 & 5 \\
Fish raw materials experience problems on the way from suppliers & A8 & 5 \\
Aspects of weather, climate, and seasons & A9 & 6 \\
Poor quality of fish raw materials & A10 & 7 \\
Lack of supplier partners & A11 & 5 \\
Poor production planning & A12 & 6 \\
Ineffective warehousing management & A13 & 6 \\
Insufficient product inventory & A14 & 5 \\
Fish raw materials run out & A15 & 7 \\
Fish raw material arrived late & A16 & 6 \\
Sudden request from a customer & A17 & 4 \\
Lack of work supervision & A18 & 4 \\
Workers who are not skilled in their field & A19 & 4 \\
Production process not according to plan & A20 & 6 \\
Lack of knowledge of market prices & A21 & 4 \\
Failure to select suppliers & A22 & 4 \\
The machine maintenance plan has an error & A23 & 5 \\
Suppliers are not able to meet the required amount of fish raw materials & A24 & 5 \\
Lack of strong agreements with suppliers & A25 & 4 \\
Choosing the wrong supplier & A26 & 4 \\
Inadequate vehicle condition & A27 & 5 \\
Transportation has been disrupted & A28 & 4 \\
Insufficient inspection & A29 & 5 \\
Few workers & A30 & 4 \\
Negligence of Occupational safety and health & A31 & 3 \\
Not obeying the company SOP & A32 & 3 \\
Production process delayed & A33 & 6 \\
Incompatibility of finished goods that consumers want & A34 & 3 \\
Alternative production is broken & A35 & 3 \\
\hline & &
\end{tabular}

Based on the risk source identification process, there are 35 risk agents in the supply chain at the Sri Tanjung Cracker Company where the occurrence rate $\left(\mathrm{O}_{j}\right)$ is 4 , namely inaccurate demand forecasting, human error, lack of coordination, and poor quality of fish raw materials, namely 7 .

\section{House of Risk (HOR) Matrix 1}

The first stage of House of Risk involves combining data on risk events, risk causes, the connection between risk occurrences, and risk causes, ARP, and ranking. At the HOR stage, the sources of risk in the Sri Tanjung Cracker Company's fish cracker production supply chain activities are identified which must be prioritized first. In the risk identification phase, the results are 60 risk events having a severity value for each risk event and each risk cause has an occurrence value of 35 risk agents. Following the 
collection of data, a correlation value will be assigned to the risk event and the risk agent. Correlation levels are sequentially grouped into values (0) that indicate no association between risk agents and risk occurrences, value (1) suggests a weak link, value (3) shows a moderate correlation, and value (9) indicates a high correlation [14].

After identifying the correlation, the ARP value is determined, to determine how to handle risk sources that must be handled first, and the risk sources are then listed from highest to lowest value. The priority causes of risk must be handled first, according to the results of data processing at the House of Risk stage 1, namely the cause of risk (risk agent) with (A4) Human error is the first rank of the source of risk. To manage the risk agent, more action is required. As a result, 35 risk agents must be dealt with in the House of Risk stage 2.

\section{Risk Evaluation}

The order of ARP values from highest to lowest is then categorized using a Pareto diagram aiming at the $80 / 20$ Pareto principle, where $20 \%$ represents the risk agent $\left(\mathrm{A}_{j}\right)$ that causes $80 \%$ of the risk event $\left(E_{\mathrm{i}}\right)$ based on the phase 1 HOR calculation. Figure 2 shows the findings of the Pareto diagram.

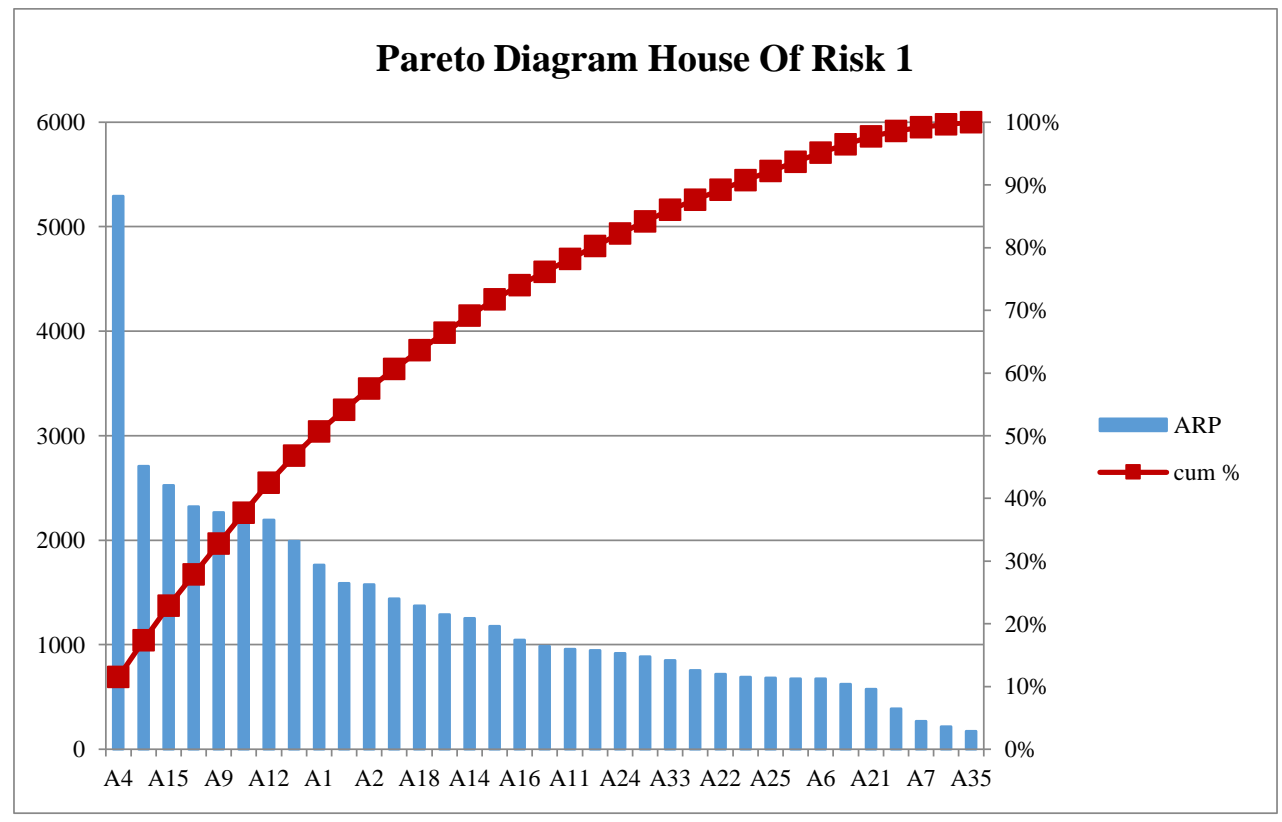

Figure 2 Pareto Diagram HOR 1

Based on the position of risk agents in the table of risk agents selected from the Pareto diagram above, 7 risk agents show the ones that have the greatest influence and need to be given priority in handling, namely (A4) human error, (A5) lack of coordination, (A15) fish raw materials run out, (A3) misinformation and communication obtained, (A9) aspects of weather, climate, and seasons, (A20) production process not according to plan, and (A12) poor production planning. 
Based on the risk agent in Figure 2 that will be mitigated, then a probability impact matrix model is made. The goal of this mapping is to see the condition of the risk before it is handled or mitigated. The following is Table 7 of the results of risk agent mapping based on the probability impact matrix model before being mitigated.

Table 7 Probability Impact Matrix Risk Map Before Mitigation

\begin{tabular}{|c|c|c|c|c|c|c|}
\hline \multirow{2}{*}{ Chance level (Occurrence) } & \multicolumn{5}{|c|}{ Impact Level (Severity) } \\
\cline { 3 - 7 } & 1 & 2 & 3 & 4 & 5 \\
\cline { 3 - 7 } & Very Low & Low & Medium & Height & Very High \\
\hline 5 & Very High & & & & & A4 \\
\hline 4 & Height & & & & A5, A15 & \\
\hline 3 & Medium & & & & A3.A9 & \\
\hline 2 & Low & & & & A20. A12 & \\
\hline 1 & Very Low & & & & & \\
\hline
\end{tabular}

Based on the risk agent mapping on the risk probability impact matrix map above, it is known that there are 7 risk agents which indicate that the priority risk agents for risk codes A4 A5, A15, A3, A9, A20, and A12 are in a critical position and need to be handled appropriately to avoid unwanted or detrimental things so that the risk agent can move to a green position and is no longer in a critical condition. After knowing the overall risk agent in the risk impact matrix probability map, it can be calculated regarding risk management through the House of Risk phase 2.

\subsection{House of Risk Phase 2 (Risk Handling Phase)}

1. House of Risk (HOR) Matrix 2

Preventive strategies will be explored in HOR phase 2 about the risk factors identified in HOR phase 1. House of Risk phase 2 is used to determine preventative activities (preventive actions) by examining the sources involved and the amount of difficulty in implementing preventive actions. Following the identification of the mitigation action (PA), then determine the level of correlation on a scale of 0 to 9 and the level of implementation of the mitigation action. Filling the correlation level and correlation level through brainstorming with experts at the Sri Tanjung Cracker Company. The total effectiveness of the handling strategy $\left(\mathrm{TE}_{\mathrm{k}}\right)$ is then calculated to determine the amount of efficacy of the handling strategy based on the risk agent's relationship.

The following step is to compute the level of difficulty $\left(D_{k}\right)$, which is used to determine the complexity of executing mitigation steps. The difficulty levels are sequentially grouped into values (3) which mitigation strategies are easy to implement, values of (4) indicate that mitigation strategies are sufficient to be implemented, and values of (5) indicate that mitigation strategies are difficult to implement based on the parameters of [15]. Then a difficulty effectiveness calculation $\left(\mathrm{ETD}_{\mathrm{k}}\right)$ was also carried out for each recommended treatment strategy. The goal of this calculation is to determine the difficulty effectiveness 
ratio $\left(\mathrm{ETD}_{\mathrm{k}}\right)$ of all the recommended mitigation strategies. The following are the results of the calculation of HOR 2 at the Sri Tanjung Cracker Company, as shown in Table 8 below:

Table 8 House of Risk phase 2

\begin{tabular}{|c|c|c|c|c|c|c|c|c|c|c|c|c|c|c|c|c|}
\hline \multirow{2}{*}{ Kode } & \multirow{2}{*}{ Risk Agent } & \multicolumn{14}{|c|}{ Preventive Action } & \multirow{2}{*}{ ARP } \\
\hline & & PA1 & PA2 & PA3 & PA4 & PA5 & PA6 & PA7 & PA8 & PA9 & PA10 & PA11 & PA12 & PA13 & PA14 & \\
\hline A4 & Human error & 9 & 9 & 9 & 9 & 3 & 3 & & & 3 & & & & & & 5292 \\
\hline A5 & Lack of coordination & 3 & 1 & 1 & 1 & 9 & 9 & & & 3 & & & & & & 2709 \\
\hline $\mathrm{A} 15$ & Fish raw materials run out & 3 & & & & 1 & & 9 & 9 & & 1 & 1 & 1 & & 1 & 2527 \\
\hline $\mathrm{A} 3$ & Misinformation and communication obtained & 1 & 1 & 1 & 3 & 3 & 1 & & & 9 & & & & & & 2322 \\
\hline A9 & Aspects of weather, climate, and seasons & & & & & & & 1 & & & 9 & 1 & & & & 2268 \\
\hline $\mathrm{A} 20$ & Production process not according to plan & & & & & 3 & & 3 & 3 & & 1 & 9 & 9 & 9 & 3 & 2268 \\
\hline $\mathrm{A} 12$ & Poor production planning & 3 & & & 1 & 1 & & 3 & & 1 & & & & & 9 & 2196 \\
\hline \multicolumn{2}{|c|}{ Total Effectiveness (Tek) } & 72246 & 52659 & 52659 & 59499 & 58750 & 42579 & 38403 & 29547 & 47097 & 25207 & 25207 & 22939 & 20412 & 29095 & \\
\hline \multicolumn{2}{|c|}{ Degree of Difficulty (Dk) } & 3 & 3 & 4 & 4 & 3 & 3 & 4 & 4 & 3 & 3 & 4 & 4 & 4 & 4 & \\
\hline \multicolumn{2}{|c|}{ Effectiveness to Difficulty (ETD) } & 24082 & 17553 & 13165 & 14875 & 19583 & 14193 & 9601 & 7387 & 15699 & 8402 & 6302 & 5735 & 5103 & 7274 & \\
\hline \multicolumn{2}{|l|}{\begin{tabular}{|l|l|} 
Ranking \\
\end{tabular}} & 1 & 3 & 7 & 5 & 2 & 6 & 8 & 10 & 4 & 9 & 12 & 13 & 14 & 11 & \\
\hline
\end{tabular}

In Table 8, the results of calculations at the House of Risk 2 stage show that the first rank of preventive action (precautionary action) that must be carried out is PA1, Strengthening supervision of worker activities ranks first as a preventive action.

2. Prioritize Every Preventive Action (Rk)

Based on the calculation of HOR phase 2, the sequence of risk management techniques is identified from highest to lowest ETD value and then classified using a Pareto diagram aiming at the Pareto $80 / 20$ principle, the same as the Pareto diagram in HOR 1. Figure 3 shows the results of the Pareto diagram.

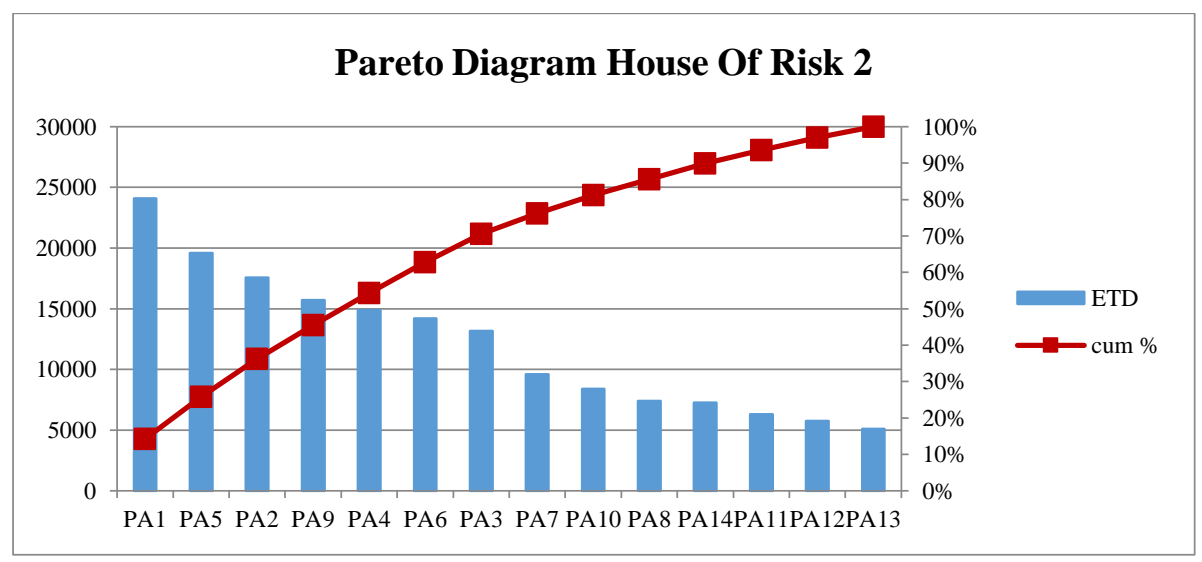

Figure 3 Pareto Diagram HOR 2

Figure 3 shows the position of the risk management/mitigation strategy in a Pareto diagram. By using the Pareto diagram, 4 preventive actions need to be taken first, namely (PA1) strengthening supervision of worker activities, (PA5) increasing coordination between workers, (PA2) conducting work assessments, and (PA9) strengthening teamwork in terms of information and communication.

After obtaining priority risk management/mitigation strategies based on the results of the Pareto diagram, the next step is to develop a probability impact matrix model. The mapping was carried out through a brainstorming process with competent parties in the Sri Tanjung 
Cracker Company. The goal of this mapping is to re-map the sources of risk after implementing a risk management/mitigation strategy. The following is the location of the priority risk sources in the probability impact matrix risk management/mitigation strategy map in Table 9.

Table 9 Probability Impact Matrix Risk Map After Mitigation

\begin{tabular}{|c|c|c|c|c|c|c|}
\hline \multirow{2}{*}{ Chance level (Occurrence) } & \multicolumn{5}{|c|}{ Impact Level (Severity) } \\
\cline { 3 - 7 } & 1 & 2 & 3 & 4 & 5 \\
\cline { 3 - 7 } & Very Low & Low & Medium & Height & Very High \\
\hline 5 & Very High & & & & & \\
\hline 4 & Height & PA1 & & & & \\
\hline 3 & Medium & & PA5 & & & \\
\hline 2 & Low & PA2, PA9 & & & & \\
\hline 1 & Very Low & & & & & \\
\hline
\end{tabular}

Table 9 shows the risk impact matrix probability map after the risk management/mitigation strategy. Before the implementation of the handling/mitigation strategy, there were 7 risk agents in a critical position but after being given a risk management/mitigation strategy, there were 4 risk mitigations in the green position, namely PA1, PA2, PA5, and PA9. This indicates that the source of risk only requires the implementation of normal risk management/mitigation strategies, monitoring, and control.

\section{Conclusion}

Based on the findings of the analysis, it is possible to conclude that the Sri Tanjung Cracker Company has a total of 21 supply chain activities using the Supply Chain Operation Reference (SCOR) model. Then there are 60 risk events $\left(\mathrm{E}_{\mathrm{i}}\right)$ and 35 risk agents $\left(\mathrm{A}_{\mathrm{i}}\right)$ in the House of Risk phase 1. Each risk agent's ARP value is obtained, which is a priority for the proposed handling strategy. According to the Pareto diagram with the 80/20 rule and mapping with the probability impact matrix model, there are 7 priority risk agents to be handled, namely human error (A4), lack of coordination (A5), out of fish raw materials (A15), misinformation and communication obtained (A3), aspects of weather, climate, and seasons (A9), the production process is not according to plan (A20), and the production planning is less precise (A12).

House of Risk phase 2 is determining a treatment strategy that can be implemented to lower the risk of risk agents. In HOR 2, 14 treatment strategies were provided based on the 7 risk agents from HOR 1. Then the results of the Pareto diagram and mapping with the probability impact matrix model obtained 4 handling strategies with the highest effectiveness values, namely strengthening supervision of worker activities (PA1), increasing coordination between workers (PA5), conducting work assessments (PA2), and strengthening teamwork in terms of information and communication (PA9). 


\section{REFERENCES}

[1] C. Kusnindah, Y. Sumantri, and R. Yuniarti, "Pengelolaan Risiko Pada Supply Chain Dengan Menggunakan Metode House Of Risk (HOR) (Studi Kasus di PT . XYZ), J. Rekayasa dan Manaj. Sist. Ind, vol. 2, no. 3, pp. 661-671. 2014.

[2] F. Tampubolon, A. Bahaudin, and P. F. Ferdinant, "Pengelolaan Risiko Supply Chain dengan Metode House of Risk," J. Tek. Ind, vol. 1, no. 3, pp. 222-226. 2013.

[3] B. R. Kristanto and N. L. P. Hariastuti, "Aplikasi Model House Of Risk (HOR) Untuk Mitigasi Risiko Pada Supply Chain,” J. Ilm. Tek. Ind, vol. 13, no. 2, pp. 149-157. 2014.

[4] I. N. Pujawan and E. Mahendrawathi, Supply Chain Management, Kedua. Guna Widya, Surabaya, 2010.

[5] A. Ridwan, D. L. Trenggonowati, and V. Parida, "Usulan Aksi Mitigasi Risiko Rantai Pasok Halal Pada Ikm Tahu Bandung Sutra Menggunakan Metode House Of Risk,” J. Ind. Serv, vol. 5, no. 1, pp. 112-120. 2019.

[6] M. E. Sibuea and H. S. Saragi, “Analisis Risiko Keterlambatan Material dan Komponen pada Proyek Pembangunan Kapal dengan Metode House of Risk (HOR) Studi Kasus: Pembangunan Kapal Ro-Ro 300 GT Danau Toba,” J. Sist. Tek. Ind, vol. 21, no. 2, pp. $28-42.2019$.

[7] A. Ridwan, P. F. Ferdinant, and W. Ekasari, "Perancangan mitigasi risiko rantai pasok produk pallet dan dunnage menggunakan metode House of Risk," Tek. J. Sains dan Teknol, vol. 16, no. 1, pp. 35-44, 2020.

[8] M. Ulfah, "Mitigasi Risiko Rantai Pasok Produk Donat Menggunakan Metode House of Risk di UMKM Nicesy,” J. Ind. Serv., vol. 6, no. 1, pp. 49-54, 2020.

[9] M. Rozudin and N. A. Mahbubah, "Implementasi Metode House Of Risk Pada Pengelolaan Risiko Rantai Pasokan Hijau Produk Bogie S2HD9C (Studi Kasus: PT Barata Indonesia)," JISI J. Integr. Sist. Ind, vol. 8, no. 1, pp. 1-11. 2021.

[10] N. Ummi, A. Gunawan, and M. Ridwan, "Identifikasi Risiko Pembuatan Kue Gipang Sebagai Makanan Tradisional Khas Banten Dengan Metode House Of Risk (HOR)," J. Ind. Serv, vol. 3, no. 1, pp. 342-350. 2017.

[11] B. Noveida, P. B. Katili, and Suparno, "Perencanaan Audit Tahunan Berdasarkan Risiko Untuk Meningkatkan Efektivitas Fungsi Audit di PT X,” J. Tek. Ind, vol. 5, no. 3, pp. 247-260. 2017.

[12] L. Nanda, L. P. S. Hartanti, and J. K. Runtuk, "Analisis Risiko Kualitas Produk dalam Proses Produksi Miniatur Bis dengan Metode Failure Mode and Effect Analysis pada Usaha Kecil Menengah Niki Kayoe,” J. GEMA Aktual, vol. 3, no. 2, pp. 71-82. 2014. 
[13] L. Afifah, S. Adji, and U. Farida, "Analisis dan Perbaikan Manajemen Risiko Pada Rantai Pasok Produk Tepung Tapioka PT. Budi Starch \& Sweetener.Tbk Ponorogo dengan Menggunakan Metode House Of Risk (HOR)," ISOQUANT J. Ekon. Manaj. dan Akunt, vol. 5, no. 1, pp. 92-107. 2021.

[14] M. Ulfah, M. S. Maarif, Sukardi, and S. Raharja, "Analisis Dan Perbaikan Manajemen Risiko Rantai Pasok Gula Rafinasi Dengan Pendekatan House of Risk,” J. Teknol. Ind. Pertan, vol. 26, no. 1, pp. 87-103. 2016.

[15] I. N. Pujawan and L. H. Geraldin, "House of Risk: Model for Proactive Supply Chain Risk Management," Business Process Management Journal, Business Process Management Journal, 2009. 